\title{
The aesthetic impact of graffiti art on modern Greek urban landscape
}

\author{
Johannis Tsoumas \\ Interior Architecture, Decoration and Design \\ Department of European Civilization \\ Technological and Educational Institute of Athens \\ Hellenic Open University
}

Recibido: 22 de septiembre de 2011

Aceptado: 18 de octubre de 2011

\begin{abstract}
Graffiti art is an expression of modern culture and, at the same time, it constitutes a counterculture in itself. Being ephemeral by nature, graffiti is an art form that celebrates change and feeds on new ideas. The street is a unique and powerful platform, a frontline where it can be expressed, transmitting personal or collective visions directly to the public at the same way as official messages. In the last two decades Greece has experienced both the effects and the side effects of globalization, from which the graffiti phenomenon would not have been excluded. The new sociopolitical and economic status quo of Greece constituted the ideal basis on which graffiti art could thrive on as it enhanced and encouraged both its ideological and aesthetic values which were meant to fight against social inequality and public litter caused by commercial advertising. However, the variety of street art and its expansion on almost every public surface of the big Greek cities, became soon a new problematic for both the citizens and the state which invented ways to face it. This research aims to focus mainly on the aesthetic impact of graffiti on the modern Greek urban landscape not only as a phenomenal way of expression, but also as a new means of controlled decoration imposed by the local authorities and the government.
\end{abstract}

Keywords: graffiti, urban landscape, social change, aesthetic pollution.

Título: El impacto estético del graffiti en el paisaje urbano griego contemporáneo

\section{Resumen}

El graffiti es una expresión de la cultura contemporánea y, al mismo tiempo, constituye una contracultura en sí mismo. Efímero por naturaleza, se trata de una forma artística que celebra el cambio y se alimenta de nuevas ideas. La calle es un escenario único y poderoso, una primera línea donde se pueden expresar y transmitir directamente al público visiones colectivas o personales a la vez que mensajes oficiales. En las últimas dos décadas, Grecia ha experimentado los efectos de la globalización, de la cual el fenómeno del graffiti no puede ser excluido. El nuevo statu quo sociopolítico y económico de Grecia constituía la base ideal sobre la cual el graffiti podía desarrollarse, ya que permitía y alentaba tanto sus valores ideológicos como estéticos, que estaban pensados para luchar contra la desigualdad social y los residuos provocados por la publicidad comercial. Sin embargo, la variedad de arte urbano y su expansión por casi todas las 
superficies públicas de las grandes ciudades griegas se convirtió pronto en una nueva problemática tanto para los ciudadanos como para el estado, que inventó maneras de afrontarlo. Esta investigación se centra principalmente en el impacto estético del graffiti sobre el paisaje urbano griego contemporáneo, no sólo como una forma de expresión extraordinaria, sino también como un nuevo medio de decoración controlada, impuesta por las autoridades locales y el gobierno.

Palabras clave: graffiti, paisaje urbano, cambio social, contaminación estética.

\section{Table of contents}

1. Introduction

2. A short history of graffiti in Greece

3. A new society, a new ideology

3.1. The power of slogans

3.2. Graffiti as an intervention of art in space

4. The advent of graffiti: a narrative of aesthetic arbitrariness

5 . The attack of image in the urban environment under control

6. Conclusions

\section{Introduction}

"Street artists are the subtitlers of the urban environment and herald an art without guardians" are the words of the American writer and art critic Lucy Lippard (1984). But what is graffiti? Is it the art form that goes beyond the limits of ideological cue and starts with colors and shapes to give new dimensions to speech? Is it the subversive art of poetic performance, symbolism, audacity, intensity and reaction? Or, is it maybe a short-term value of expression of a status quo of some anonymous or famous artists driving all of us, the unsuspecting viewers, into an orbit of a timeless swing between a new perspective of life and vandalism? For many decades now, starting from the New York underground and applied to almost any surface in the large cities of the world, it has been an integral piece, embracing their modern critical and active elements acting as a term synonymous with the urban culture. Nevertheless, its place in art is not clear yet, so for many people it constitutes a rather para-artistic phenomenon but due to its aesthetic and ideological specificity it emerges as a very interesting topic of the urban landscape (Iosifides 2002).

Modern, newly-built Greece, a peculiar architectural mixture of a centuries-old historical heritage and a shoddy, deliberately destructive reconstruction, in terms of its architectural style, after the Second World War, has become a particularly appropriate platform for the implementation of this globally cultural phenomenon. Borrowing modern ways of personal and collective public expression of cultural roots, fundamentally different from the hitherto Greek data, such as street art or otherwise graffiti, it is a particularly 
appealing topic for study and analysis from a socio-political and aesthetics point of view as it seems to influence seriously the urban landscape in Greece. This research is not designed simply to list items for the birth and growth of this phenomenon in the country, or to support one of the two sides of its inconsistency, but rather to focus on its existence as an innovative form of expression that affects directly and clearly the aesthetic shaping of the urban landscape, mainly in Athens but also in other cities, through the reflections of the diverse political, social, biotic, aesthetic and structural changes taking place today, in the Greek social fabric. More specifically, from within a short historical report of graffiti in Greece, we will move on to the newly established social and political situation in the country, focusing on its major upheavals from 1990 onwards, while trying to link them with the two most important, in our view, forms of this new kind of ideological and aesthetic expression. While doing this, we will attempt to identify its conceptual and aesthetic expansion and proportional impact on the urban landscape of the country, observing at the same time the various prevention and control measures taken by the respective governments or local authorities for its "safer" application, from an aesthetic point of view, to the public view areas.

\section{A short history of graffiti in Greece}

The roots of the term "graffiti" touch upon the ancient world and occur as a means of encoded communication on the walls of buried Pompeii or the Roman catacombs, but even in earlier times, in Ancient Greece. Etched designs of individuals, heroes, gods and goddesses, and phrases or slogans were even at that time a kind of vandalism, as they were usually applied on surfaces of public buildings as a form of protest or admiration. Etymologically, it derived from the word graffito, which refers to works of art originating from the artist's attempt to draw shapes on a surface, stems from the purely Greek word grafein (OED 2006). In medieval times one can observe the application of characters or phrases etched on the walls of public and private buildings, particularly in the then capital of the Byzantine Empire, Constantinoupolis and other cities such as Athens and Corinth. Many of the engraved phrases and slogans were curses or prayers, and many of the designs depicted scenes of battles, ships or people of significant value to the creator (Gregory 2010).

However, several centuries went by before one could observe in later Greece a similar mass movement of protest, of defense or other social reaction, as the sociopolitical facts did not support such a form of resistance.

During the German occupation (1940-1945), small or large resistance groups, used 'graffiti' as an alternative form of weapon (with the 'illegal' resistance notices) to awake and empower the humiliated and totally exhausted Greek people against the fascistic 
imperial vanity. Its implementation on public sight surfaces, such as large yards, ruined houses, flattened factories, walls and bombed harbor piers, had a significant slogan-driven power, without any natural aesthetic perspective.

The sociopolitical events of the critical decade of 1960 (Junta of the Colonels 1967-1974), brought forth again the need for the Greek people to protest against the unjust and immoral society through the vilification slogans written in white or red paint on the walls and the playgrounds of cities and villages. The era after the Junta (1974-) was stigmatized by a bombardment of political slogans, but the most persistent and repeated type of slogan has always been the one that expresses the anarchic-autonomous perception. Thus, the term 'graffiti' was connected painlessly with the need for expression against oppression and for the free democratic will, while acquiring a historical, monumental value.

Many years later, Greece of the mid 1980's began giving birth to the flakes of a new cultural renaissance which, although it had its roots in substantially the same ideology, had then been reformed and restructured radically. Modern graffiti was increasingly emerging as a new phenomenon for the Greek reality, though it was slow to actually get its final form beyond the political or social cues dominating, as we saw, in previous decades.

\section{A new society, a new ideology}

The socio-political changes in the map of the Greek reality over the last two decades have been devastating. The transition of political chariot after a short-lived stay in the center-right field, in the already known paths of socialist power which was to keep the country under control until nearly the mid-2000's marked an important development for society and economy. Some of the results are: a) the revolution of the private radio and television broadcast which resulted in uncontrolled and directed information, but also in reducing the number of cultural and educational programs, and in impairing the quality of many hitherto entertainment programs; b) the degradation of Education with the introduction and the experimentation of a series of new non-effective models on all levels; c) the massive entry of illegal immigrants mostly from the Balkan countries, initially, and their subsequent massive influx in the country from many poor countries of Asia and Africa which marked the beginning of the deterioration of the large cities socio-economic profile, that is where they were gathered aiming at their permanent or temporary installation before continuing their journey to other European Union countries, raising feelings of insecurity, racism and xenophobia in the 
local population ${ }^{1}$; d) the swelling of anarchist groups which kept multiplying, along with an increase of crime, violence in the stadiums and the environmental problems began to account for issues of utmost importance for the average Greek.

At the same time, the urban landscape of the cities was more or less the same: the results of the consideration were boring, thankless residential complexes in the center, but mostly in the surrounding working class neighborhoods, few recreation and green areas with large industrial units within the cities or in the nearby regions, untapped, even poor, historical monuments, sites of enormous cultural significance, small roads with huge traffic jams and few buildings of traditional architecture ${ }^{2}$. Furthermore, the environmental problem had already begun to be, especially in the densely populated city of Athens, a major issue of perpetual, social and political conflict without a solution.

In the already existing situation, compromised from a quality point of view -especially since the 1970's- another form of abuse was added stemming from the imperatives of a shady corporate propaganda which advocated the violent distortion of public spaces with views of huge posters, slogans, banners of stores, or other messages of commercial interest. The walls, columns, bitumen, the roofs of buildings, the railroad trains, but also the lateral surfaces of buses, constituted a fertile ground for profit for many multinational companies, making public places and public transport areas where rights were only conferred to those dealing with trade. However, even

\footnotetext{
${ }^{1}$ Greece as a country confronted the first large wave of immigrants in the early 1990 's, that is, when the fall of the so-called "Eastern Block" led to a massive descent of Russians, Bulgarians, Romanians and Georgians and about 600,000 Albanians. Having not yet been able to handle this situation, Greece had to face as well the second wave of immigrants from Iraq, Pakistan and many African countries in the early 2000's. Over the past twenty years the people of Athens are the ones who have most frequently encountered this phenomenon because so far, they see their city emerging as a centre of attraction, subject to radical changes. Similar problems are also plaguing the cities of Patras, Thessaloniki and Piraeus.

${ }^{2}$ The contribution of land for partition is a Greek phenomenon which does not apply to other parts of the world, at least to such an extent and in such a form. It is a building method used heavily in Greece during the postwar period and this is why it is said to date back to the late 1950's. It was applied as a solution worked out to cope with the acute housing problem caused in large cities (especially in Athens) because of the huge accumulation of population there which was the result of the Asia Minor Catastrophe (1922), the devastation caused during the II World War (1940-1945) and the subsequent Civil War (1945-1949). The application of this consideration has resulted in divergence of the country's course from its traditional vernacular architecture and urban history and the corresponding structural systems of other European countries. In the 1950's, but especially during the 1960's and the 1970 's, there was an uncontrolled development of buildings in the center, but mainly at the periphery of the cities. The city expanded haphazardly, so the illegal construction and the demolition of abandoned buildings and traditional architecture got massive proportions.
} 
political propaganda through posters, which was especially intense that year, seemed to compete vigorously with commercial expansionism. We see then that the aesthetic and functional insult from which the urban landscape suffered was painful, since one more part of the already low quality living of the Greek cities had begun being challenged (Andriotakis 2003).

All these combined with many other issues remind us of the concept of "urban culture" which, in this case, looks completely distorted, mainly because the city is not a static habitat, but rather a dynamic state of perpetual change and variability over which living and survival should be also coped with, and the human mind begins to search for fixed points of reference to navigate through, especially in the vast urban environments.

So the new generations, hatched in high schools and colleges of that time and obviously influenced by the bombardment of new cultural norms -initially through the TV and then via the Internetsoon discovered a new way of aesthetics and social action, coming from the "imperialistic" American culture. For this reason, in the early 1990 's, graffiti started to become a fashion, and then a mass way of artistic expression, as well as of personal and popular protest. More specifically, the wave of graffiti, developed at that time in Greece, was characterized essentially by two potentially expressive means: a) the slogans and $b$ ) the visual.

\subsection{The power of slogans}

Signage, slogans, notations, verbal reactions were perhaps the easiest, but the least painless way of massively implementing this new, for the Greek society, form of public expression. Closed, groups and individuals initially dared to try slogan-type interventions in several public spaces among which on the Hellenic Railways Organization and the Electric Train carriages (figure 1). The first, experimental messages soon expanded into squares and benches, bridges, public toilets, and walls of private buildings and even shutters and shop fronts, expressing the anger and the individual, political and social concerns of the new generation of Greeks. 


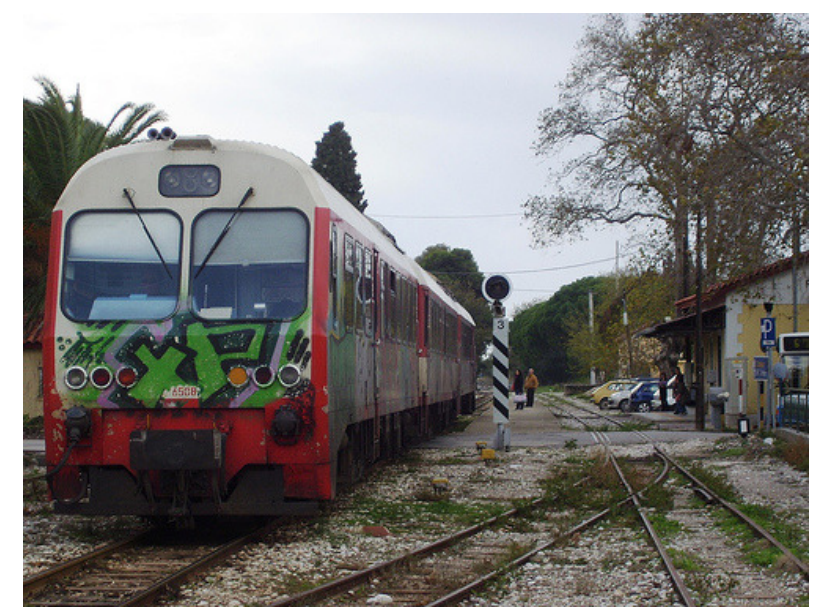

Figure 1. The engine of a Hellenic Railways Organization train, covered with a vividly colored graffiti slogan. Central Railway Station of Thessaloniki, 1993.

Obscenity was often confused with philosophy or resentment through terse, smart, satirical, blaming and often provocative slogans. Sprays, paints, the technique of stencil and markers were the first of the new tools of the young objectors, who generally with an easy-to understand font, began to form a new semantic language that addressed to frantic target groups through almost all surfaces visible to the public (Manco 2006). Their creations were often slogans of foul language which seemed to dominate in areas where teens made their first breakthrough, such as walls and courtyards of public schools, wall surfaces around sports facilities (mainly soccer), football fans' meeting points (cafés, clubs), vacant lot, land and squares all of which became places of expression through often violent, threatening or fanatical symbols and slogans (figure 2).

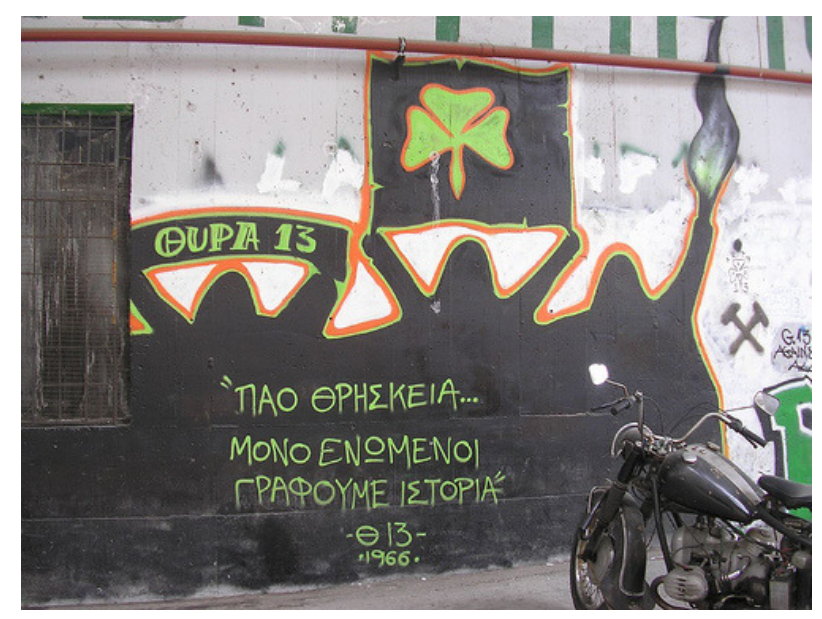

Figure 2. 'Panathinaikos is our religion; only united we can leave our traces in history', is the main slogan of this football team fans' graffiti. Athens, 1995. 
The political activism in the students' of higher education communities (Universities and Technological Educational Institutions) was strongly promoted through slogans in graffiti, with a particular action taken by left-wing political parties members such as K.N.E. (Communist Youth of Greece), SYNASPISMOS (Coalition) and SY.RIZ.A. (Coalition of the Radical Left) and later the ruling party at that time P.A.S.O.K. (Panhellenic Socialist Movement) and the centerright opposition NEA DEMOKRATIA (New Democracy). The status of political posters soon started to collapse giving way to large and vibrant wall messages of sociopolitical content both inside and outside the campus, especially in the central parts of the cities. Anarchist groups resorted to the method of graffiti with subversive slogans and symbols of their ideas against the social establishment served by the former ruling class, while their voices were frequently joined with the foreign-language cues of the weak and socially marginalized illegal immigrants who inhabited the big urban centers of the country, especially since the mid 2000's (figure 3). In these cases graffiti seemed to act as a dividing sense of the areas in which the above groups moved and acted, defining them informally as "inviolate" and inaccessible social centers of minorities. Several areas of Athens, such as Exarchia, Vathi Square, Omonia Square, Koumoundourou Square, Neos Kosmos, but also individual parts, such as bridges and subways, soon emerged as parts of a dangerous social movement which hosted in fact sites of social conflict and controversies (Stefanou 2010). Opposed to the above, were the reactionary voices of parties and organizations of the extreme right, such as the CHRISSI AVGI (Golden Dawn), a political organization of fascistic ideology and the PATRIOTIKI SYMMACHIA (Patriotic Alliance), a minor political scheme of nationalistic character, whose positions were less extreme though, highlighting the first social cues of racism and xenophobia, especially in the areas surrounding the alleged immigrant ghettos, but also in many depressed areas of the cities.

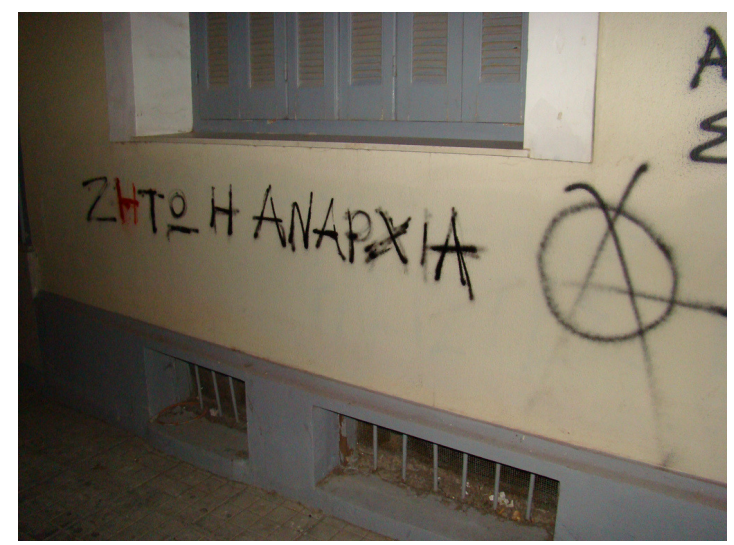

Figure 3. Slogan on the façade of a private building bearing the characteristic symbol of anarchism. Exarchia area, Athens, 1998. 


\subsection{Graffiti as an intervention of art in space}

Along with the flourishing of slogans as a form of "street art" in several Greek urban areas one can observe, especially since the beginning of the 1990's, similar efforts to create ideological and artistic interventions in many areas of public view in the cities. Their aim was the promotion of their own creators (writers) as most of these types of graffiti were only their personal, idiosyncratic signatures (tags), widely known as colorful, whimsical, "three dimensional" ideograms (figure 4). Furthermore, the creation of pictorial representations, diverse in genre and style, but obviously influenced by the world of comics and cartoons, (urban imagery) appeared soon. Not only did the subjects of these graphic rather than artistic pictures focus on simple and painless aesthetic ideas, but they also undermined important aspects of Greek and world issues (the traffic problem, the environmental pollution, the unemployment, the urban loneliness and the subsequent alienation of people, the human rights, the peace between peoples and so forth).

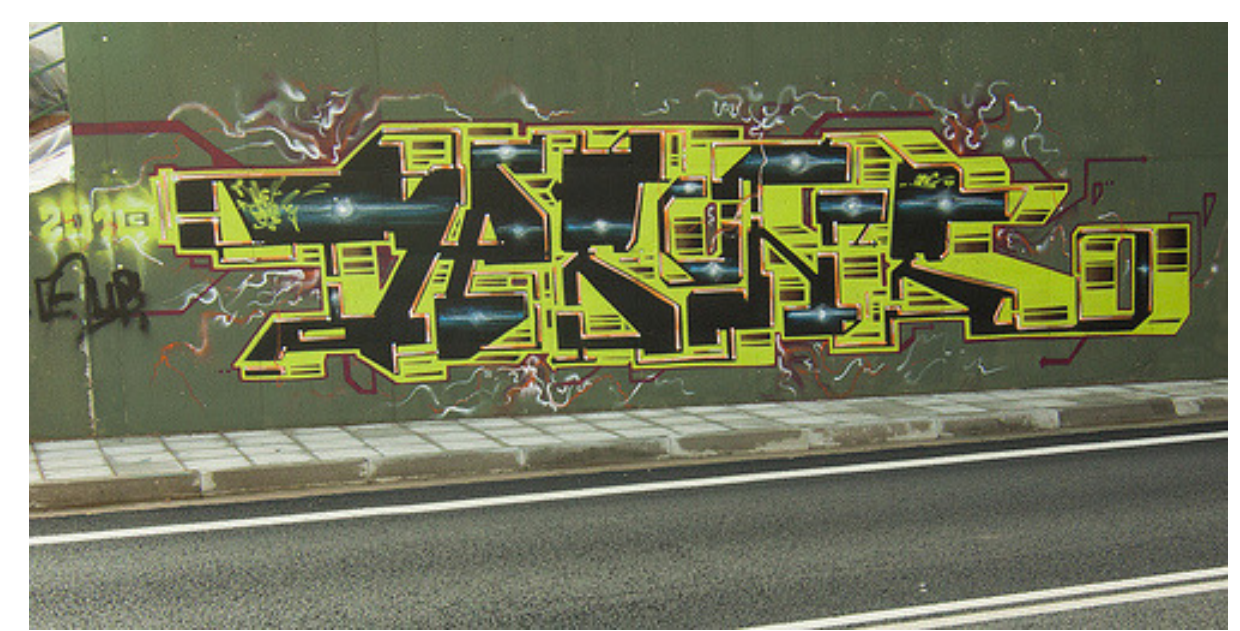

Figure 4. A colorful composition of graffiti lettering under a central bridge in the city of Agrinio, 1999.

It was no longer than the term graffiti-expert was established and consolidated in the common vocabulary of either individuals or groups engaged in this form of ideological expression. For them it represented the anti-social young person who, in an effort to communicate feelings of hopelessness, despair, anger, rebellion and protest against the sociopolitical status quo, resorted to the power of word and image "tarnishing" a public view area (Kanta 2011). However, the aesthetic ideology of many other creators, in most cases well known individuals or groups, represented a reactionary line against the ugliness and monotony of the damaged architectural Greek urban landscape, but also a significant response to any additional aesthetic corrosion imposed on them by the propaganda of many multinational companies through advertisements. 
By the late 1990's featured writers, as well as groups falling in with this new, unprecedented aesthetic initiative for the Greek society started becoming known to the general public, seeking acceptance ${ }^{3}$. However, many members of these groups had already had a structured relationship with the field of arts, and were either students or graduates of the then two major public art schools of the country (Athens School of Fine Arts, School of Fine and Applied Arts of the Aristotleleion University, Thessaloniki). Names of individuals such as Bansky, jnior, Seim, and groups such as Carpe Diem in Athens and homo, Jason, SBG and $2 G$ in Thessaloniki began to grow their appearances in parks, squares, bridges, walls, factory walls, surfaces of old and abandoned cars or buildings, but also on the ground floor or sides of buildings, even on the surface of public bins ${ }^{4}$. The attempt to bridge the gap of human communication in the cities of the country, and to adorn the gray urban landscape with colors and designs through this type of pictorial writing, led to the concept of mural art, which is probably considered as the re-introduction of the art history term of mural, adjusted proportionately to the needs and resources of the modern era. Thus, this aspect of graffiti art began to write its own history from the central areas down to the poor districts and neighborhoods of the large urban centers of Greece, demonstrating once again the world power of the American cultural expansionism (figure 5).

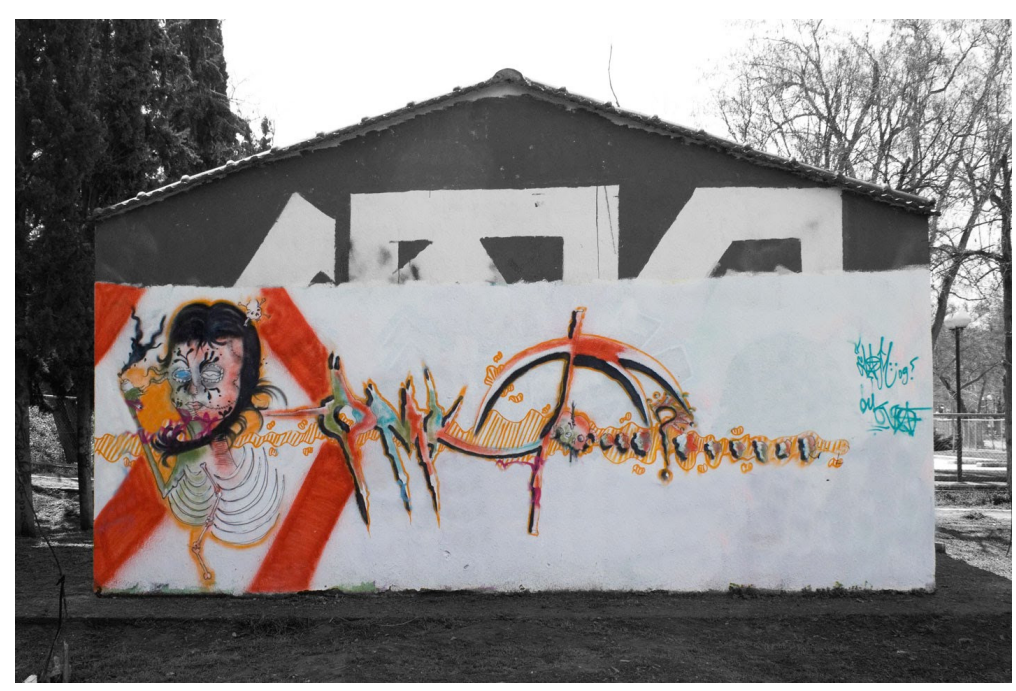

Figure 5. An attempt of mural art through the graffiti technique on one side of a private building in the outskirts of the city of Larissa, 1999.

\footnotetext{
3 The assistance from like-minded foreigners (Can2, Kent, Delarosa and many others) to the effort of the Greek writers was very important, as these persons visited frequently the country to guide and advise many people, especially young artists.

4 The 'Carpe Diem' team was founded in 1988 by people of various nationalities with the common vision to promote the art and the techniques of this alternative culture through the application of mural art in several public places.
} 


\section{The advent of graffiti: a narrative of aesthetic arbitrariness}

According to architect Panos Dragonas, associate professor at the University of Patras "graffiti proliferates in cities and communities in crisis. New York of the 1970's, London at the time of Thatcher and modern Sao Paulo constitute examples of cities flooded with graffiti when they experienced major social upheavals and inequalities". Similarly, the Greek graffiti, especially in Athens, the city from where it started and spread to the rest of Greece, suggests the cultural crisis in the modern Greek society, the disintegration of public space and the new deadlocks. At the same time, however, it is a primary ideological and aesthetic expression of an emerging urban culture (Rigopoulos 2010). Under this perspective, we can realize the rapid spread of graffiti in all major cities of the country, starting in Athens adding, however, that its massive uptake, in contrast to the aforementioned cities, is not observed in the fringe groups, but in people from the middle class because it was precisely that one which developed the major problems of social inequality in Greece. Specifically, in the early 2000's, that is when social class divisions, along with globalization, were increasingly growing, the uplift of graffiti particularly in the urban landscape of the Greek district became more intense. In the same period there was a gradual transition from simple, often printed, wall slogans to pictorial messages and ideas (Theodosis \& Karathanassis 2008).

Greeks seemed to have already shown enough tolerance to the arbitrary script in public areas, thus it is no wonder that its replacement by images, symbols and shapes became, at least initially, accepted (Manco 2004). Soon the sovereignty of the image over the slogans became undeniable, claiming an important position not only in urban memory, but also in the 'linguistic' significance of the Greek urban environment. Greek graffiti started by then to form a new communication language, based on international characteristics but it was never adapted to the cultural and historical context of the Greek society and remained unchanged, highlighting once again the power of globalization. On the other hand, though, graffiti constituted a successful reflection of the Greek society whose chauvinistic characteristics had been obsolete by then, because the changes it had been through had already rendered it multicultural.

With a massive expansion in every corner of the city, not only did graffiti resist the aesthetic pollution of consumerism through outdoor advertisements, posters, foreign language or other signs of shops and businesses, but it also began to form with them the New Greek linguistic landscape (Muñoz Carrobles 2010). In particular, although diametrically different, both ideologically and aesthetically, these two sides of an iconographic and semantic interest eventually managed to coexist and build over time a new language of visual storytelling of urban lifestyle, occupying an important place in the 
modern Greek urban culture history. However, their differences in proportion to how and where they were applied, were great: outdoor, commercial advertisements, captions, inscriptions, and most of the posters were a controlled way of information, as they had specific information and, in most cases approved -although not necessarily appropriate- application places. On the contrary, graffiti constituted a form of unregulated information that was applicable almost anywhere.

In the first three years of the 2000's we witnessed a massive tendency of graffiti application on public and private places, beginning to claim everything. Its non-discriminated presence in schools, historic buildings, monuments and statues, archaeological sites, churches and cemeteries, parks, public buildings, private houses and shops, cars, trains and stations, vacant lot, and half-ruined buildings were for their creators the principle for aesthetic upgrade. Nevertheless, delving deeper into this issue we note that such an intervention in an already fragile structured environment should have had a more substantial formation, targeting, and feasibility. However, in conjunction with the mundane postwar building constructions and commercial advertising, some of the admittedly high graffiti art works began to be an important part of an urban problem which in time took the shape of huge 'cluster' or 'fronts' in a large part of the Greek cities, mainly in the outskirts. Marketing 'habitats', especially along the major roads of the cities, but also on the focal points of neighborhoods (private spaces, and infrastructure), were 'enriched' with more aggressive application of graffiti, which contributed to the further deterioration of the physiognomy of the already degraded urban environment (Bieratos 2007). Soon, many, underdeveloped areas which received this 'aesthetic assault' of graffiti became synonymous with "dumps" as street art began to be conceived as a new form of aesthetic pollution (figure 6). 


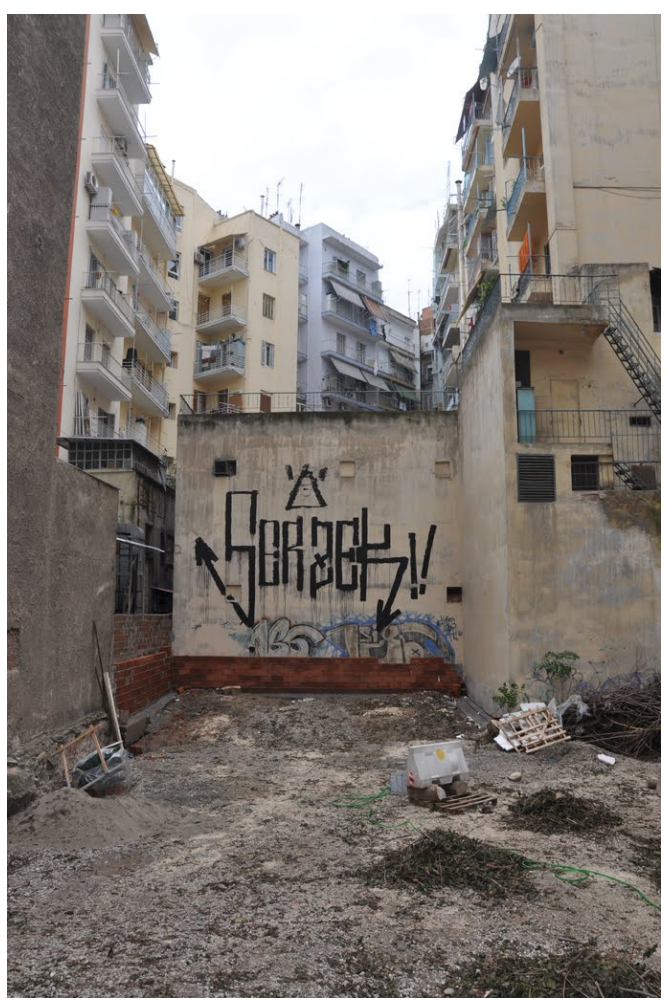

Figure 6. Graffiti was soon associated with a form of aesthetic pollution especially in the underdeveloped areas of the big Greek cities. Thessaloniki, 2002.

Similarly, the irrepressible application of graffiti on the historical centers of the Greek cities and especially in neo-classical monuments or buildings, apart from being seen as a sign of vandalism and destruction, also caused the reactions of both citizens and the State $^{5}$.For example there was an inquiry-complaint raised by the members of the Democratic Left Mr. T. Leventis, N. Tsoukalas, and C. Psarianou to the Ministers of Interior Affairs and Culture on "the aesthetic deterioration" of the historic center of Athens through graffiti. As they remarked:

[...] in the historic Plaka neighborhood, archaeological sites, monuments and adjacent to the facades of historic buildings that

5 For several individuals from the world of Greek thinkers the interventional and "disrespectful" approach of graffiti to public areas linked with the history and culture of the country could be compared to the first manifesto of the Futurists (Italy, early twentieth century). In fact, this probably allowed or even promoted the release of the reaction of many intellectuals of that era against the 'museum' character of Italian arts and the inactivity of Italian artists during the nineteenth century. Consequently, they called for the destruction of libraries, museums, academies and the cities in general which had become like mausoleums. On the other hand, they praised the beauty of revolution and war, the significance of speed and the power of modern technology. Other than the rejection of the past and the apotheosis of the present and future, this ideology also featured elements of anarchism as it seemed to attack the bourgeoisie. 
adorn the area and most of which are owned by the state and house services of the Ministry of Culture, one can find the uncontrolled activity of spray, which is not an artistic intervention, but rather a kind of smudge. (Zonews 2011)

The same practice, but also similar reactions occurred in many other places of historic character of other Greek cities, such as the monuments of Thessaloniki, the northern tower of the ancient walls of Veria, places of traditional architecture of Xanthi, Kastoria, Nafplio, Chania and other areas of historical value across the country, highlighting the serious threat of this 'imported neo-aesthetic pollution'.

\section{The attack of the image in the urban environment under control}

All this led the then government to proceed with the bill voted for the 'protection of public and private property' from the vandalistic extension of graffiti. But it was no other than the local authorities in Greece which ventured to open the adoption of innovative proposals and ideas aimed at the healthy and smooth integration of this new cultural phenomenon into the already beleaguered urban landscape. A pilot training program which was implemented initially in elementary schools, aimed at raising the students' interest to clean and protect the statues and the monuments of Athens from graffiti, as it was considered that the issue of "color pollution" of the city was a purely educational issue. Along with cleaning crews, students learned to love history and to devalue graffiti recognizing it as a carrier of ugliness and destruction. By doing this, they also accepted to "adopt an injured statue" as the motto of the characteristic campaign of the City of Athens had defined it (Otanews 2011) (figure 7).

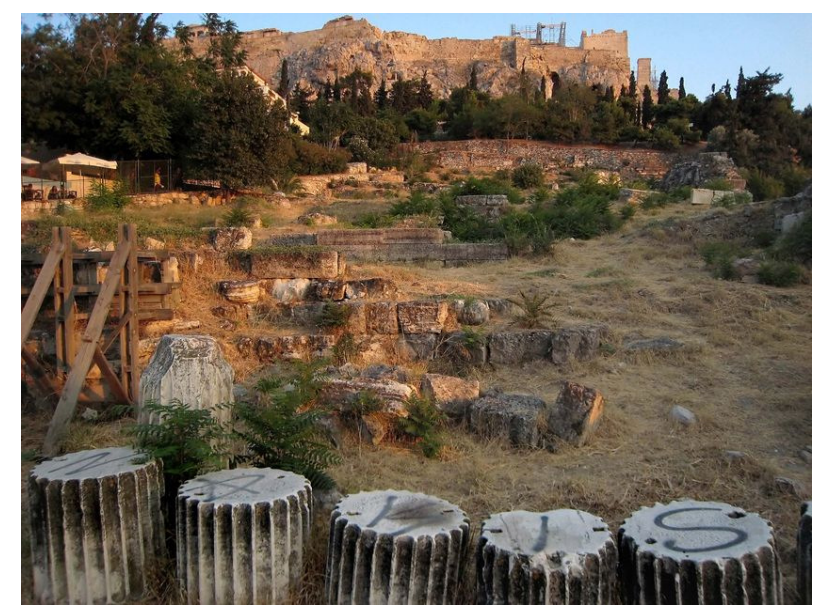

Figure 7. These ancient ruins destroyed by graffiti writers constitute a unique example of the uncontrolled application of 'street art' on the modern Greek urban environment. Athens, 2002. 
After 2004, the effort of the Athens municipality, but also the support of the General Secretariat for Youth appeared to affect other municipalities of both small and large cities of the country, many of which did not focus on the disapproval of graffiti in public view areas. On the contrary, they proceeded to organize special two or three day festivals which they promoted by welcoming the aesthetic qualities of 'street art', although it had to be applied on concrete faces after seeking approval from the municipal authority (facades or masked faces of cultural and intellectual centers or even walls of municipal athletic centers, playgrounds and schools). In this way, they had no aspirations to promote the subculture of graffiti, but rather to manipulate it, by simply including it in the conventional aesthetic measures for their urban areas, challenging its ideological background and limiting its expansion. The technique of short-lived, outdoor murals, free theme, was that one which was considered to be the most suitable for the aesthetic upgrade of the selected surfaces, but mainly for the relief of young artists ${ }^{6}$. Very quickly such events became very popular both throughout Greece and Europe, while they are still considered of having an "institutional nature".

Along with these graffiti festivals, many cities in the country also proceeded to the implementation of several pilot projects which referred to the aesthetic improvement of public and private buildings made to measure through visual interventions based on the graffiti art. This time the relationship between local authorities in each region with the creators of the murals was purely professional, and the institutions attempted either the direct award of contracts or sponsorships. The main goal was to upgrade aesthetically the central and peripheral parts of the cities, and the attempt to overthrow the practice of the up to then gray and dirty urban landscape. These programs included many successful projects that were applied on specific fields (the "front-Public Murals Reformation at Psiri" project in Athens), on buildings of a specific functionality (the "Drawing School" project across Greece) or on specific building parts (the "Painting facades in Greece" project) (Iosifides 2008). During a period of seven years, thank to these programs, over five hundred buildings have been included in the respective programs, in many of which the works for their rehabilitation have already been completed, while more than two and a half thousand people, organizations or companies have expressed their interest in such an artistic intervention on their premises. The success of these efforts is based not only on the proper selection of each building and the area where it lies, but mainly on the interactive relationship that develops every

${ }^{6}$ The life of graffiti is very limited due to both the external conditions in the cities and its components. An average term of its resistance is from eight to ten years. 
time between the artists, the responsible bodies and individual owners and users of the murals in the buildings, even the residents or the passers-by of the areas around them. The implementation process is open to the public and everybody is given the opportunity to participate therein (figures 8 and 9).

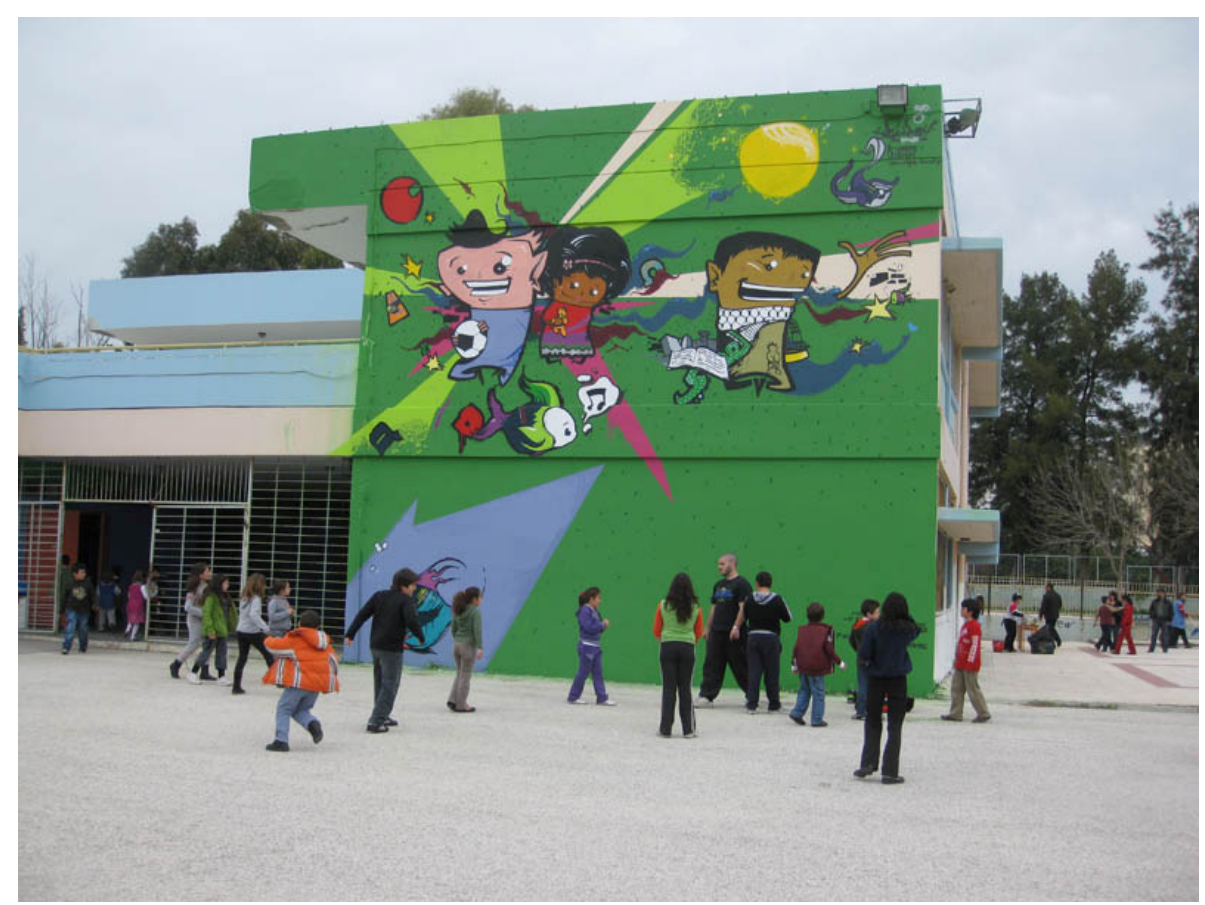

Figure 8. An effective modern mural on the façade of a school in the area of Aegaleo, made by the 'Carpe Diem' team, 2007.

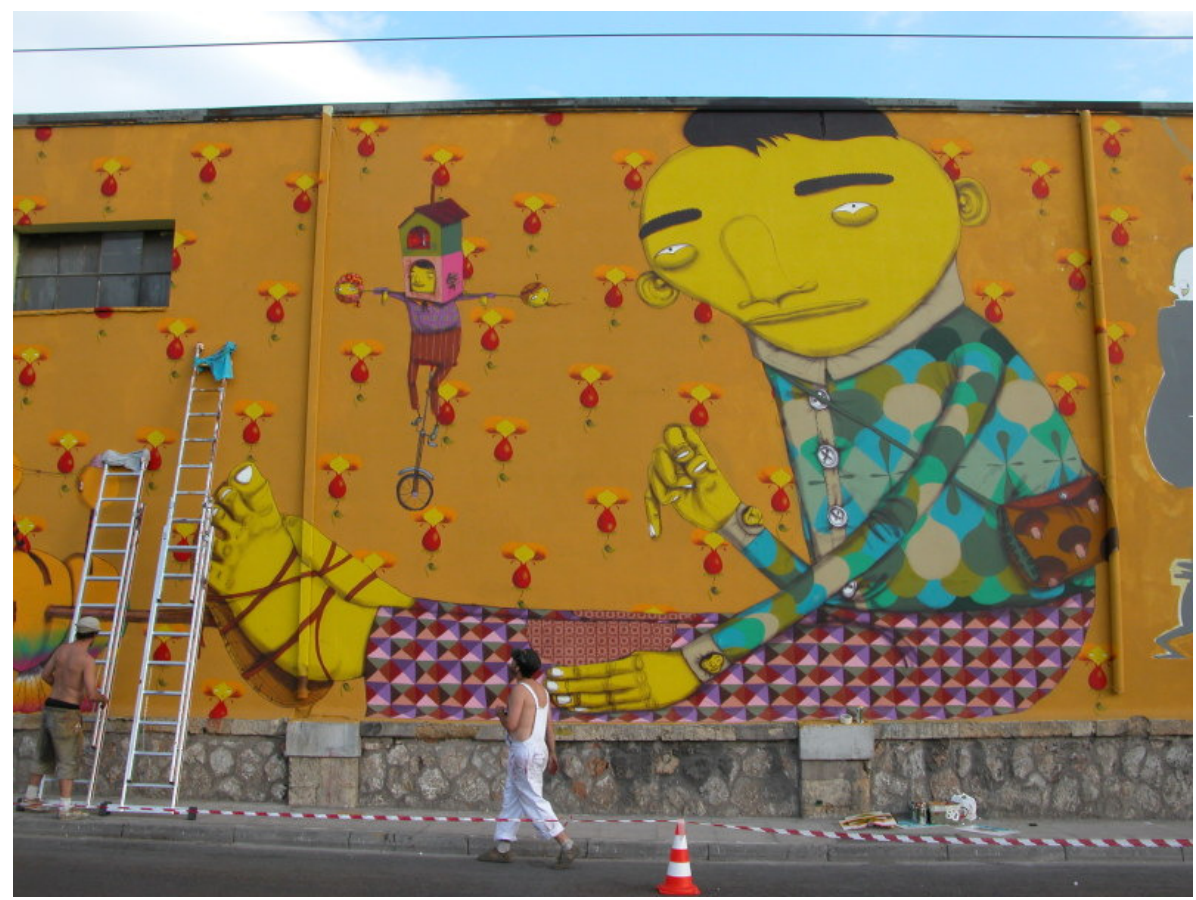

Figure 9. Graffiti mural work on a factory façade, in process.

'Carpe Diem' team, Athens, 2008. 
With a lot of delay, but with less ambitious mood, it was not until 2010, on the initiative of the newly established Ministry of Environment, Energy and Climatic Change in the governance of P.A.S.O.K., and on the dominant contribution of the School of Fine Arts of Athens, that a new experimental program based on the model already implemented by the major cities of the country, was applied. The murals on five buildings in some heavily populated and underdeveloped areas of Athens were only the beginning of the artistic intervention of the Ministry which was headed: "Painting of blind-sided buildings: color on the grey parts of the city". These buildings were selected among another thirty eight ones and the criteria of their selection were both the viewing of works of art so as to upgrade the visual aesthetics of neighborhoods and their geographical distribution in areas with different social composition for the sake of fairness. Their artistic beautification is, in the opinion of the competent institutions, a flexible and inexpensive intervention, the advantages of which are the possibility of moving them to both the center and the regional parts the country and the possibility of adapting the works of art to the scale of the buildings selected. Initially, however, the objective of the Ministry and the School of Fine Arts was to implement interventions in a total of forty-blind sides of buildings of Athens and then the massive action of artists whose main subject is the art of graffiti for shaping the urban public space within the larger program "Athens-Attica 2014".

All these efforts of the Greek State to harness the new urban phenomenon seem to have a multiple feasibility: a) to develop the environmental, social and aesthetic consciousness of the Greek citizens, especially the younger age groups through educational processes, and thus through the management of graffiti as an inspiration for improving the urban environment and diminishing their 'guilt' as a form of social decay and aesthetic pollution; b) to halt the phenomenon as an uncontrolled form of mass expansion and to achieve its greatest possible downsizing; c) the contribution of graffiti and murals in the broader effort to improve the quality of the Greek urban environment; d) the importance of art in the urban landscape as a tool for growth and optimism, especially in times of social or economic crisis like the current one, and e) the controlled formation of urban memory through art activities approved with an immediate effect on the physiognomy of the urban landscape. 


\section{Conclusions}

The aesthetic impact of graffiti on the modern Greek urban landscape was a "second thought" of their creators as their initial target was to create an innovative form of political, social and personal protest. Despite the later intention of graffiti to be the opposite of the aesthetic pollution of outdoor advertisements, its frequently uncontrolled application to non-probationary places and surfaces, soon made it their synonym. Undoubtedly, however, its massive expansion in less than twenty years in public view areas in the major urban centers of the country, led to discussions, debates, bickering and alliances, respectively, not only on its artistic value, but also on its involvement in shaping both a new type of urban environment and a broader urban culture. The Greek people as a whole met with skepticism the massive "invasion" of graffiti into areas and places of public and private interest, and many times they condemned it despite its high technical and aesthetic qualities. The reaction of the State in this new social and aesthetic phenomenon that seemed to "threaten" the aesthetic character of the primarily large, urban centers of the country was slow to appear.

However, the intention to harness the uncontrolled action of graffiti in many experimental efforts such as graffiti festivals and the award to create murals in many areas of Athens, Thessaloniki and other cities, was not late to become imperative. But beyond all these, Greek graffiti never ceased to exist and proliferate, covering an increasingly bigger number of areas of public view, even today.

Its aesthetic sense is directly linked to its ideological identity and this is why, despite any state or political aspirations, its domestication is not proved, neither is it easy or feasible. So in conclusion, we must admit that the aesthetic impact of this new art, which is a figment of globalization, on the urban landscape will always depend on the sociopolitical scheme within which the concept of modern city develops and it will always be an important benchmark in the urban memory of Greece. For this reason above all, the aesthetics of graffiti with regard to the Greek urban environment cannot be viewed and analyzed individually and independently of its ideological base. Nor can it integrate into any kind of framework of aesthetic autonomy, as pursued by the Greek State, because it may lose both its independence and identity. The intervention of street art in shaping the modern Greek urban landscape will always be a new proposal of ideological revolution rather than an autonomous movement of its aesthetic upgrading or degradation. 


\section{Bibliography}

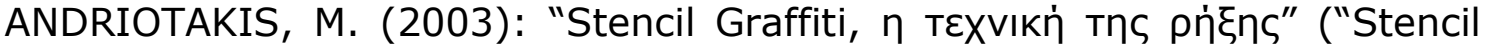
Graffiti, the technique of clash"). Eleftherotypia, issue 145, pp. 12-14.

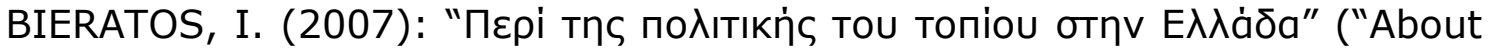
landscape policy in Greece"). Cephalonia Chronicle, issue 15, pp. 2022.

GREGORY, T. E. (2010): A history of Byzantium. West Sussex: Blackwell Publishing Ltd.

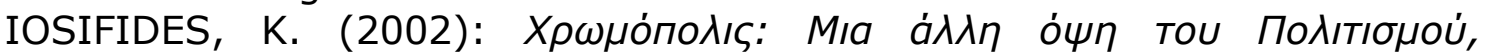

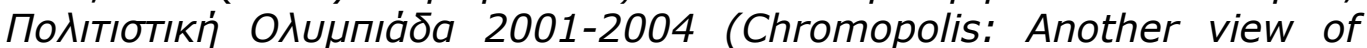
Culture, Cultural Olympics 2001-2004). Athens: Akti-Oxy Publications.

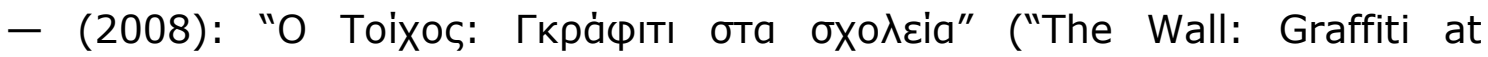
schools"). Geotropio, issue 452, pp. 40-42.

KANTA, M. (2011): "Graffiti: the street art". Newsport, issue 116, pp. 1820.

LIPPARD, L. R. (1984): Get the Message. A Decade of Social Change. New York: E. P. Dutton Publishers.

MANCO, T. (2004): Street Logos. London: Thames and Hudson Ltd.

- (2006): Stencil Graffiti. London: Thames and Hudson Ltd.

MUÑOZ CARROBLES, D. (2010): "Breve itinerario por el paisaje lingüístico de Madrid" [on line]. Ángulo Recto. Revista de estudios sobre la ciudad como espacio plural, vol. 2, núm. 2, pp. 103-109. En: http://www.ucm.es/info/angulo/volumen/Volumen02-2/varia04.htm

OED (2006): "Graffito", in Oxford English Dictionary. Oxford: Oxford University Press.

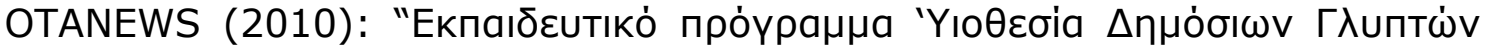

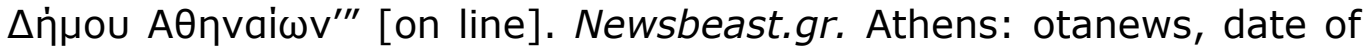
publication $18 / 10 / 2010$.

In: http://www.newsbeast.gr/culture/arthro/61989/uiothetise-ki-esyena-agalma/ (accessed in 15/12/2010).

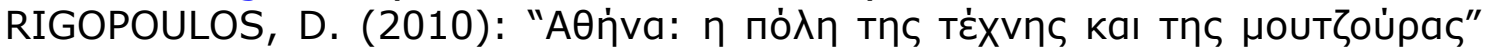
("Athens: the city of art and stain"). Kathimerini, issue 359, pp. 1214.

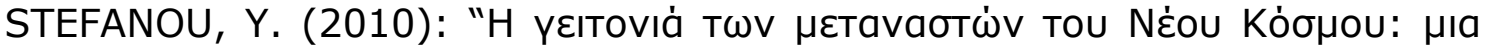

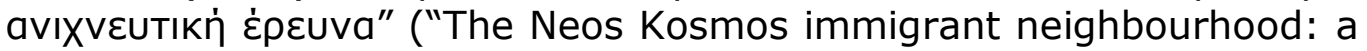
tracing research"), in Report no. 6, pp. 38-44. Athens: Panteion University of Social and Political Science.

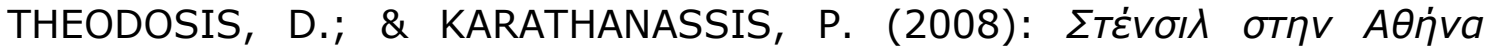
(Stencil in Athens). Athens: Oxy Publications.

ZONEWS (2011): "тa tags бто кह่Vтро" [on line]. Zonews.gr. Athens: Zo stin Ionia, date of publication 01/02/2011. In: http://www.zonews.gr/index.php?showbody=i\&articleid $=6080$ (accessed in 10/03/2011). 